\title{
Neoliberalism and global capital mobility: a necessary reconsideration of textbook trade theory*
}

\author{
KUNIBERT RAFFER**
}

RESUMO: A teoria dos livros didáticos ignora os fluxos de capital: o comércio determina as taxas de câmbio e de especialização. São necessárias abordagens que levem em consideração os movimentos de capital adequadamente, e uma nova teoria da política econômica, incluindo medidas para proteger a economia real da volatilidade externa. O mecanismo de equilíbrio de livros didáticos não pode funcionar para definir as taxas de câmbio. Para que a teoria ortodoxa do comércio funcione é preciso impedir que os fluxos de capital destruam a sua própria base, causadas pelo FMI por decisões regulamentares erradas, penalizando a produção e o comércio. Uma teoria nova, baseada na economia real é proposta, uma agenda neoclássica de controle de fluxos de capital e da especulação.

PALAVRAS-CHAVE: teoria do comércio; especialização; movimentação de capitais; neoliberalismo; especulação.

ABSTRACT: Textbook theory ignores capital flows: trade determines exchange rates and specialisation. Approaches taking the effects of capital movements adequately into account are needed, and a new theory of economic policy including measures to protect the real economy from external volatility. Equilibrating textbook mechanisms cannot work unless tradecaused surpluses and deficits set exchange rates. To allow orthodox trade theory to work one must hinder capital flows from destroying its very basis, which the IMF and wrong regulatory decisions have done, penalising production and trade. A new, real economy based theory is proposed, a Neoclassical agenda of controlling capital flows and speculation.

KEYWORDS: trade theory; specialisation; capital movements; neoliberalism; speculation. JEL Classification: F11; F13; F32; F40; G15.

Once upon a time the exchange rate was basically determined by the movement of goods and to a lesser degree, services, at least in textbook trade theory. Although free capital movements — on a much lower scale than nowadays - existed for a

\footnotetext{
* For valuable comments I am indebted to Luiz Carlos Bresser-Pereira.

** Universität Wien, Fachbereich Wirtschaftswissenschaften, Österreich. E-mail: kunibert.raffer@univie. ac.at. Submetido: 5/Agosto/2014; Aprovado: 13/Outubro/2014.
} 
short period of time before WWI, textbooks virtually did not consider their impact on exchange rates, let alone on real production and trade. After all, the gold points would keep exchange rates within ranges determined by real exports, the costs of transporting gold from one country to the other. The real economy thus normally determined the exchange rate. Capital flows existed but were of subordinated importance. Capital controls were generally used, except by countries subscribing to the gold standard and for a relatively short period of time. Economic textbooks therefore focused on imports and exports as the variables determining exchange rates. They have not changed appropriately when capital started to flow freely around the globe in the age of neoliberalism. This paper is going to reassess trade in view of the present dominance of the financial and speculative sector.

The present situation differs strikingly. This is probably best characterised by one simple ratio. In the late 1990s, when the UNDP again triggered the discussion on the Tobin Tax, all international trade of one year amounted to less than four days of capital transactions. There were no longer any gold points limiting exchange rate movements either. As exchange rates are determined by supply and demand of currencies, it is easy to see that whatever pressure on the exchange rate might be exerted by the real economy, the effects of international trade in goods and services can be easily outdone by demand caused by capital movements, speculative or otherwise. To put it strikingly: the real sector is dominated by capital movements even if they have no or little basis in the real economy, as has increasingly become the norm. Naturally, this changes all the assumptions of trade theory and trade textbooks - the effects of capital flows may annihilate any productivity gains or textbook advantages. It may suddenly make patently incompetitive exports highly profitable as long as the exchange rate is depressed by capital movements or prevent highly competitive exports if the currency revalues. Country A specialising according to textbook theory may suddenly find itself unable to trade simply because an inflow of capital caused, e.g., by quantitative easing in one or two big countries and the concomitant fall in interest rates there, pushes comparatively high inflows right into country A, where interest rates are and should be higher. This increase in the exchange rate annihilates any trade policies. Exports and specialisation otherwise optimal according to traditional textbook theory simply become too expensive and incompetitive. Speculative-flows-induced exchange rates may change quite quickly, much more quickly than any producer in the real economy would ever be able to shift production, unless we use textbook assumptions that changes of production structures can be done within split seconds and at no cost. In real life shifts are likely to be more problematic, often creating great damages. As usual, reality does not live up to neoclassical perfection - unveiling another advantage of orthodox economists vis-à-vis natural science. While the latter change models that prove wrong in reality, orthodox economist have advanced to ignoring such mere facts while busily creating an even more absurdly unrealistic model on their blackboards. In addition, capital inflows will frustrate policy efforts to manage the economy via the domestic interest rate. Decades of neoliberal liberalisation of capital flows have not only allowed the self-destruction of the financial sector (saved by large amounts of taxpayers' money, though) and destroyed whole countries, as the present crisis proves, but also destroyed the usefulness of neoclassical textbook 
trade theory, which continues to be preached even more untouched by new realities than it had been by the problems of real trade before.

Obviously, there is a need for new approaches taking the effects of capital movements adequately into account. Speculation and its effects will by definition always remain unpredictable - but what can and must be done is developing a theory of how to neutralise dangerous capital inflows and exchange rate variations. A new theory of economic policy is also needed that includes measures to protect the real economy from external volatility. In a world that cannot adapt as quickly and easily as textbook models, this is mandatory - if and only if one heterodoxically and unashamedly posits that economic theory should at least somehow reflect reality, a demand no "good" economist would raise. The long record of neoliberal crashes and catastrophes, from Chile 1982 to Europe at present corroborates this demand forcefully. Mainstream economists nevertheless react as one would predict: their models were right but reality was not. Thus, no need to change mainstream models.

This paper sketches the role and importance of capital flows in economic theory and policy, contrasting these in old and new textbooks and in economic policy before and during the era of neoliberalism. It shows that controlling capital flows is in a way a homecoming to traditional ideas - held also but not only by Keynes - that took into account the common interest and were prepared to subordinate private profits to the common good. Even hard nosed $19^{\text {th }}$ century capitalism saw it as the task of the government to assure that short term, speculative private gain may not destroy whole economies or create huge damages. Policy advice and ideology that allows three banks to bankrupt a country, as in Iceland, is obviously good neoliberalism and consequently very bad economics. The banking sector was therefore regulated by $19^{\text {th }}$ century liberals, which means that technically profitable business was not allowed in order to safeguard the stability of the system. This old liberal attitude - still the base of Bretton Woods (cf., Helleiner, 2014) — was superseded by the one credo of neoliberalism: greed, complemented by the belief that losses must be socialised, the damages done by a maverick banking sector and wild speculation must be paid for by taxpayer's money, briefly by present economic policy. Nevertheless, orthodoxy pretends old trade theory to hold.

\section{TEXTBOOK TRADE THEORY AND THE EXCHANGE RATE}

The famous Ricardo-Torrens theorem of comparative advantages, still the main textbook item in trade theory, excludes capital flows altogether. The real economy alone determines comparative advantage. It is customarily presented using the otherwise academically outlawed - labour theory of value. Methodologically this does not fit in with neoclassical economics, but apparently anything goes as long as it confirms mainstream ideology. The mere fact that convenient $2 \times 2 \times 2$ models cannot be generalised has, e.g., never been stressed, even though the world has slightly more than two countries and arguably more than two goods are traded. Results disproving ideologically wanted results were put to oblivion. The Graham Paradoxon, e.g.,, still discussed in the 1930s by Viner (1937), who could not dis- 
prove it but honestly presented it nevertheless (cf., Raffer, 1994), have just disappeared from textbooks and teaching.

Since cloth is not physically bartered for wine, however, comparative advantages really work via exchange rates, a fact usually simply overlooked. Defending the theorem, Emmanuel (1972, pp. 240ff) points out that Ricardo first expounded it in "The High Price of Bullion" and that he contemplated two scenarios in his Principles, with metallic or convertible currency and fiduciary and inconvertible currency. Thus, Emmanuel argues, the theorem does not depend on the labour theory of value but on exchange rates. Customarily, the theorem is connected to the pure theory of trade not monetary trade theory. Many authors connect comparative costs essentially to barter, characterising it as not necessarily applying to a money economy. Even though Samuelson (1948) writes "To do justice to the theory of international trade, we must be willing to admit the possibility of capital movements" (ibid., p. 407), he is unwilling to explore the effects of drastic exchange rate changes brought about by these flows on real trade. Instead, he remarks that countries could pay their imports by IOUs and default on their debts afterwards. Nothing

in the pure theory of comparative costs $[\ldots]$ prevents the world from continually obligating itself to pay (in the future) for more American goods than it can pay for by barter. There is nothing in the theory from [sic!] preventing such one-way borrowing from leading to periodic financial collapse - to be followed by a renewal of the same process after confidence and gullibility have been restored. (ibid.)

Exchange rates come only in to reflect Samuelson's fears that the "Dollar Shortage" may lead to eventually unpaid US exports. This might have been a relevant topic at that time, but can hardly qualify as an incorporation of exchange rate effects on trade flows.

In textbook theory, exchange rates are brought about by trade not by capital movements. These are totally absent in Ricardo-Torrens, as well as with HeckscherOhlin trade theory, the Marshall Lerner condition, Stolper-Samuelson or the Rybczynski theorems. Briefly, the whole body of conventional trade theory rests on models without capital flows. In a way this even applies to Emmanuel's (1972, pp. xxxiiif; on his model cf., Raffer, 1987) unorthodox Unequal Exchange theory, although he based it explicitly on the assumption that capital is internationally mobile. Capital in his model means only capital that is internationally sufficiently mobile to establish one rate of profit in physical production globally. Beyond these Marxian prices of production approach, capital flows do not determine trade patterns. Capital in the sense of speculative flows, carry trade etc. remains as disregarded as by orthodox textbook trade theories. Emmanuel shows, however, that exchange rate changes caused by trade in goods and services really allow the comparative costs theorem to function in more realistically designed models. But he also does not go any further to combine exchange rate movements with real trade.

Viner's (1937) textbook on trade does not contain much on international capital flows (ibid., pp. 599-601 is one rare example to the contrary), though domestic 
monetary policies influencing nominal prices and thus ultimately export prices are widely analysed.

To make his point regarding exchange rates, Emmanuel simply assumes that Ricardo's values express national currency instead of units of labour, i.e., the elements of the matrix are escudos and pounds respectively, not hours of standardised labour:

$\begin{array}{lcc} & \text { Wine } & \text { Cloth } \\ \text { Portugal (esc) } & 80 & 90 \\ \text { England (sh) } & 120 & 100\end{array}$

"It is clear that, despite the comparative costs, at 1 escudo $=2$ shillings Portugal can sell nothing to England, whereas England can sell anything to Portugal" (Emmanuel, 1972, p. 241). This triggers the monetary mechanism. Via the trade balance equilibrium of 1 escudo $=1.25$ sh is eventually established, without any change in nominal, domestic prices. At this rate, English cloth sells in Portugal at 80 escudos, annihilating her domestic textile industry, while Portuguese wine commands a price of 100 sh, 20 sh less than Kentish wine. The theorem works in full swing.

Obviously, at an exchange rate of 1 shilling = 1 escudo, England could not sell anything at all. At $1.5 \mathrm{sh}$ per escudo Portuguese wine would cost as much as wine from Kent if we disregard transport costs as usual in trade theory and exchanging money would not cost anything. Clearly, there exist an upper and a lower limit for trade to be economically possible, set by the exchange rate. We may call it the trade interval. Global bartering is not really a practical option. In practice, one would also have to factor in the exporter's exchange rate risks unless the two currencies are pegged, e.g., via a currency board or as in Asia before the crisis.

Thus, Rose \& Van Wincoop (2001) see the benefits of currency unions in lower trade barriers, more trade and higher welfare, estimating that trade barriers associated with national borders - national money, really — are halved when countries join a currency union. Politically, this is stressed, for instance in favour of the eurozone, while orthodoxy and the same politicians otherwise recommend flexible exchange rates.

If we introduce capital flows of the magnitude neoliberal deregulation and liberalisation of capital markets have brought about in tandem with revolutionary changes in communication techniques reducing transaction costs for capital to virtually zero, comparative cost specialisation may become irrelevant or impossible. Interest rate differentials between countries - as in the cases of the Asian crisis or crises in Latin America — explain capital movements. Eichengreen and Mody (1998, p. 39) identified declining interest rates in the major money centres as an important trigger: "US interest rates fell by 50 per cent between 1989 and 1991. By 1992 shortterm rates in the United States were at their lowest level since the early 1960s." One should expect interest triggered flows to react in a highly unstable way vis-à-vis changes in interest rate differentials. This danger was clearly seen by Eichengreen and Mody before the "Tequila crisis" erupted at the end of 1994, even warnings were published in IFI-publications. The rise in Northern interest rates occurred in 1994 as predicted. It "was associated with a curtailment of capital flows and the sharp shock to confidence now known as the Tequila crisis" (ibid.).

Therefore, economic policies of some globally important countries, e.g., QE 
(Quantitative Easing), do not only drive down domestic interest rates but also trigger capital flows. Cheap money policies - by the US Fed or the ECB - are made without any consideration not unduly to distort trade. This is not on their radar. Their concern is not comparative costs or trade, but interest rates in order to stimulate investment, to keep lending costs of the respective sovereigns low, or - mostly in the case of the ECB - to bail out recklessly speculating banks with cheap money denied to sovereigns. The ECB grants commercial banks riskless business by providing money at close to zero interest, which banks can lend on to euro-members at high interest rates (unless they prefer using them for speculative bubbles), a taxpayer funded corporate welfare scheme. Central banks not only encourage capital outflows that increase exchange rates of the countries flooded by capital, they also cheapen production within their own boarders via exchange rate changes. Capital recipient countries increasingly deprived by bilateral treaties of any defence against this mechanism thus face two negative effects on their exports. Corporate capital naturally goes to where it gets more returns, especially so if bail-out programmes can be relied on to keep them out of harm's way, preventing the market mechanism from working, and bonuses are paid out well before any crisis erupts. This is plain vanilla micro-economics. Changes in interest rates may trigger immediate repatriation of capital. If the exchange rate is pushed beyond the trade interval, all effects and incentives of textbook trade theory are overridden. The present case of Switzerland defending against capital inflows due to the catastrophe created by the EU's debt mismanagement pushing the exchange rate up and damaging Swiss exports substantially, is just one telling example of a country with solid and traditional economic policies. News in mid-June 2012 that the Danish central bank considered negative interest rates to fight off the massive influx of funds resulting from the acceleration of the eurozone crisis is another example of proper policy reaction.

Exchange rate elasticities will, of course, be less high than pure theorists may expect, especially in the short run. Spare parts for existing equipment cannot be bought anywhere. Consumer preferences - such as a taste for Swiss chocolate or German cars - will dampen export losses at least temporarily and within limits. But the equilibrating textbook mechanism cannot work because the exchange rate is not set by trade caused surpluses and deficits. Falling exports may well exert downward pressure, but inflows of capital may easily overcompensate this and prevent a fall in the exchange rate. Comparing the dimensions of real trade and financial flows it is easy to see that this result is not unlikely at all, especially so in the case of relatively small economies.

If one assumes - in contrast to orthodoxy - that production capacities and shifts cannot occur as quickly as one can click one's fingers, shifts into and out of the trade interval - even abrupt shifts within the interval - cause considerable damage. Investment into what at the moment is remunerative production would appear too risky. This seems to be one reason why investment has been so weak recently.

Briefly, in order to allow orthodox trade theory to work one must hinder capital flows from destroying the very basis of orthodox trade theory. This would also have the positive non-academic side-effect that manufacturing industries in the South are not destroyed either.

Textbooks have reacted to the changed situation, though not sufficiently so. 
Krugman and Obstfeld (2009, p.533) identify the "claim" that "the swift adjustment of market determined exchange rates would help countries maintain internal and external balance in the face of changes in aggregate demand" as one major argument in favour of floating exchange rates. The authors point out, however, that destabilising speculation "might have negative effects on countries' internal and external balances", and - under "Injury to international trade and money market disturbances" - they point out that floating rates "would make relative international prices more unpredicand thus injure international trade and investment"(ibid., p. 537). Pointing out that using "forward markets and other derivatives expanded dramatically, just as advocates of floating had foreseen, and innovative financial instruments were developed to help traders avoid exchange rate risk" (ibid., p. 555) they finally come down on the side of floaters, not without pointing out correctly, though, that such instruments are not costless. The problem of massive exchange rate shocks on the real economy is not further discussed even though the real (actually producing) economy is forced to bear these costs.

This attitude is mainstream. To quote just one example: the IMF's (2014, p. 154) directors noted

that the appropriate policy measures will differ across emerging market economies, but observed that there are some common priorities. Exchange rates should be allowed to respond to changing fundamentals and facilitate external adjustment. Where international reserves are adequate, foreign exchange interventions can be used to smooth volatility and avoid financial disruption.

In view of literature on irrational behaviour of markets (such as herd behaviour) the IMF upholds that the "market", however rigged by speculation or otherwise in reality, is always right. In spite of its own caveats against high reserves as a threat to the global economy - expressed most clearly in its concern on global imbalances (cf., Raffer, 2011) - this is simply ignored when it comes to defending violations of the Fund's own statutes and its employees' present ideological views: members are encouraged not to use capital controls in such a situation. Although the $\operatorname{IMF}$ (2014, p. 122) warns: "Adverse external financing shocks hurt economies more when they tend to be more exposed to capital flow volatility" the fault lies routinely with the country. "Directors noted that the recent increase in financial volatility likely reflected renewed market concern about fundamentals" (ibid., p. 153), or "The renewed increase in financial volatility in late January of this year highlights the challenges for emerging market economies posed by the changing external environment. The proximate cause seems to have been renewed market concern about emerging market fundamentals" (ibid., p. xv). Thus, internal reforms within emerging economies, allowing exchange rates to respond freely, lower budget deficits, and "a new round of structural reforms" including the "removal of barriers to entry in product and services markets" are generally needed, although appropriate policy measures will differ across countries (ibid., p. xvi). May these few quotes suffice to show that crimethink, the idea that - especially big and quick - exchange rate movements might not be caused by changing fundamentals (which 
usually need some time to change) is not affecting these directors' minds - selfcensorship at its very best.

\section{SPECULATION AND COMMODITY MARKET: THE DIRECT LINK TO TRADE}

The interconnection between trade and financial flows is arguably most direct in the case of commodities, that have absorbed a huge amount of money in the recent past. Kaufman (2011) reports that the commodities futures market increased from a "sleepy $\$ 13$ billion" in 2003 to $\$ 318$ billion in June 2008. During the first 55 days of 2008 alone, "speculators poured $\$ 55$ billion into commodity markets" (ibid.). Since the bursting of the tech bubble in 2000 , there was a 50 -fold increase in dollars invested in commodity index funds.

In cocoa markets speculators were estimated to account for nearly 40 percent of the world's harvest. Open positions that are doubtlessly dwarfed by the relation real economy-financial flows, but can nevertheless have quite strong repercussions on trade by those, who need cocoa to produce.

Obviously, this creates problems economic textbooks chose to remain unaware of, though analysing them in different settings elsewhere. Driving up exchange rates — and markets are known to overshoot — commodity speculation may trigger hog cycles. But unlike the textbook Cobweb case it is not production that causes cycles but exchange rate swings caused by speculation wholly independent of real production. No doubt, countries benefit from it as long as the fad lasts. But whenever the tide turns and money leaves in as panicky a way as usual, all investments suddenly turn into losses. Upholding the credo of orthodox economics - rational expectations - rational investors must anticipate these swings and not invest during booms. In contrast to rational expectations disciples, though, history proves that rationality is largely absent with real life economic actors as the present crisis clearly proves. The only rational expectation left seems to be that speculators will be bailed-out by taxpayers.

Extensive literature exists on speculative bubbles, herding, fads and other behaviour driving market prices away from equilibrium values, even in a market which is deep and liquid. This destroys the foundation of the very trade theory on which liberalising markets - including markets for capital without any theoretical but all the more ideological underpinning — is based. Such evolutions are just what the founders of the Bretton Woods system wanted to preclude, giving trade proper and its theory the basis for working as expected.

\section{BRETTON WOODS - ENHANCING TRADE BY KEEPING CAPITAL FLOWS UNDER CONTROL}

After the experience of beggar-thy-neighbour policies in the 1930s, the aim of Bretton Woods was to re-liberalise trade, a typical textbook agenda. The mutual 
choking off of export revenues should not be repeated. By contrast, capital controls were not only welcome but should remain one important part of the system (Helleiner, 2014). The still existing articles in the IMF's Articles of Agreement were drafted deliberately and did not just slip in accidentally. Keynes and White shared the view that international finance should be under greater public control. Helleiner (no year, p. 3) stresses the differences between the gold standard era and the 1920s, when the "Brussels International Financial Conference of 1920 had passed a resolution condemning all barriers to the international movement of capital", and Bretton Woods, where "an international agreement endorsed the use of capital controls in a comprehensive and unambiguous manner." Of course, at that time the automaticity of the gold points had finally been buried.

Basically establishing a liberal regime for trade — the precise term is "current transactions" including more than purely trading activities - the IMF's articles of Agreement allow an array of capital controls, as Malaysia illustrated during the Asian crisis to the Fund's dismay. But even "current transactions" can be restricted pursuant to Art. XXX(d)(3), which only subsumes "payments of moderate amount of amortisation of loans or for depreciation of direct investments", or Art. XXX(d) (4) subsuming "moderate remittances for family living expenses" (stress added KR) under current transactions. Art. VI(1)(a) stipulates that members are not allowed to use the Fund's general resources to meet a large and sustained outflow of capital. The Fund may even "request a member to exercise controls to prevent such use of the general resources of the Fund. If, after receiving such a request, a member fails to exercise appropriate controls, the Fund may declare the member ineligible to use the general resources of the Fund." Members are only entitled to make reserve tranche purchases to meet capital transfer. All the quotes above are from the still valid though routinely violated statutes of the IMF. As Helleiner (2014) documented so well, the IMF has "redefined" (illegally one must add) its initial goals to the detriment of its "weaker members."

Reality, however, has been different from what the founders wanted. The present discussion and "news" such that the IMF is now reconsidering its position on capital account liberalisation are outright ridiculous. They are tantamount to saying that IMF finally considers obeying and applying its own statutes and respecting the rights of its members even if and when that is in the interest of the South or runs counter its own - or rather its employees' - ideological predilection.

In open violation of its own statutes the IMF has forced crisis countries not to exercise their right, thus causing considerable damage to member economies. Bringing the Rule of Law to the IMF by making it respect its own statutes and the use of membership rights during crises would allow sensible measures to defuse crises cheaply and fairly. Making the IMF financially accountable would enhance the market further (cf.,., Raffer, 2010, pp. 230, 237). Unfortunately, no member had ever taken up this issue in general terms, not even Malaysia when she exercised her statutory right. No other country followed or has picked this up. While it is easy to understand why no one affected challenges the legal base of behaviour resembling donations "voluntarily" given to young, well trained males with sunglasses in Sicily, one wonders in this case. The point is, however, that no one can 
free others. People only can free themselves, standing up for their rights, as the real history of the abolition of slavery shows.

Additionally, they would bring market risk to bear, thus substantially reducing the present moral hazard situation where speculators and investors have reason to expect being bailed out and — last but not least — the IMF and other IFIs gain from crises, even if they have caused them. In crises they are "needed". By contrast the absence of crises leads to problems, as the shrinking of IMF drawings and importance that caused severe financial problems just before Iceland's crisis showed. Iceland's deregulation and liberalisation crash saved the IMF, one of the main actors and advocates responsible for deregulation and liberalisation crises such as the one that damaged Iceland.

\section{THE IMF IN THE AGE OF NEOLIBERALISM: DESTROYING THE BASIS OF TEXTBOOK TRADE}

In spite of the very clear formulation of its Articles of Agreement and recent empirical evidence, the IMF (Ostry et al., 2011, p. 4) and its staff continue cling to old ideological preferences

First, capital controls may be useful in addressing both macroeconomic and financial stability concerns in the face of inflow surges, but before imposing capital controls, countries need first to exhaust their macroeconomic-cum-exchange rate policy options. The macro policy response needs to have primacy both because of its importance in helping to abate the inflow surge, and because it ensures that countries act in a multilaterally-consistent manner and do not impose controls merely to avoid necessary external and macro-policy adjustment.

One must not forget that the IMF has been the one main actor in promoting neoliberal changes, forcing such changes on member countries in debt distress, knowingly violating its own statutes, membership rights and the Rule of Law. The Fund still claims that the real economy should first try to adjust, allowing control only after these options are exhausted. A quick look at dimensions ridicules any such notion. One may point out that this is officially not the IMF's view, as this document like so many others contains the caveat that it "does not necessarily represent IMF views or IMF policy". One then should wonder why the totally private view of authors had to be officially "Authorized for distribution by Olivier Blanchard". In my case, no one has - or is legally entitled to - authorise whatever I am saying.

Looking at the wording closely, the paper speaks of "necessary external and macro-policy adjustments" - but who determines which changes are necessary? Also, necessity depends on the policies and goals pursued. Economically, costs of shifts should also be taken into account. 


\section{WRONG REGULATORY DECISIONS PENALISING PRODUCTION AND TRADE}

It must not be forgotten that Northern regulatory measures fostered crises and exacerbated problems created by capital flows, increasing their speed and volatility. The risk weight given by the Basle Committee to short run flows, or regulatory changes necessary to allow institutional investors to invest in Mexican tesobonos before 1994-95 are examples. Without this liberalising regulatory move this Mexican crisis could not have taken place. It started with Basel I. The capital and credit risk measurement system commonly referred to as the Basel Capital Accord. Since 1988, this framework has been progressively introduced in virtually all countries with internationally active banks as the Committee's homepage (BIS, 2011) proudly states.

Basel I was a reaction to the 1982 debt crisis, in particular to the sad fact that US money centre banks had to face it without appropriate reserves, mainly because of regulatory failures, but also due to their extraordinary obliviousness to the risks of lending - an exemplary market and regulatory failure. While European banks had been encouraged to provide for losses by their regulatory and tax system and were able to take substantial losses (cf., Raffer, 2010, pp. 93ff), such losses would literally have wiped out Wall Street banks in 1982. While loan loss reserves were encouraged in Continental Europe, US tax laws obstructed this built-in stabiliser. Scientists - as opposed to orthodox economists - would have started to think and analyse. Rather than adapting Continental European best practice - the UK did so to some extent by her matrix system - the US could successfully push through Basel I. This, again, raises questions. As Basel has reduced the capital blanket needed by banks, this was also in the interest of the financial sector. Propagated as a framework to stabilise the system, Basel in reality increased its fragility. The costs of these ill-advised decisions had to be borne by the poor in the South and taxpayers in the North.

Basel I focused on risk weighted capital adequacy, unduly disregarding the stabilising potential of proper provisioning rules. It explicitly demanded lower capital weights for short term exposure in the South, thus positively encouraging shifts to shorter maturities. Such short term lending is not conducive to investments in the real economy. The basic idea, to give lower weights to less risky claims, is theoretically correct. In practice, however, those risky short term flows were encouraged that brought about the Asian crash of 1997. The Basel system accorded a low risk weight of 20 percent to claims vis-à-vis private banks in non-OECD countries with maturities up to, and a weight of 100 percent with maturities exceeding one year. Thus, revolving could quickly and simply be denied, cutting recipient states off capital flows. Investments in the real economy were penalised. Simultaneously, the IMF insisted on keeping the capital balance open, demanding high interest rates within debtor countries that chocked off economic activity. Andrew Crockett, then General Manager of the BIS and Chairman of the Financial Stability Forum, explained at a hearing at the German parliament, the Bundestag, that this problematic decision may be seen a micro-macro problem. For any individual loan a shorter maturity means ceteris paribus less risk than a longer one. But if "all loans to Thailand are with three-months maturity" (Bundestag, 2001, p.66) there is a problem, their effect becomes highly destabilising. A correct observation, but as rules 
and norms are made for all lenders rather than for the odd out loan, this macroeffect was foreseeable, only the Basel Committee was obviously unable to foresee it. In contrast to Asian governments, the Basle Committee was hardly criticised.

International financial institutions seconded this tendency, pushing Asian countries to go on liberalising and deregulating speedily. Ex post, the $\operatorname{IBRD}(1999$, p. 3) lectured Asia that the "unprecedented volume and reversibility of short-term capital flows, weak banking institutions and ineffective regulation systems proved a lethal combination." Not for the first time. Stating that "[M]any fundamentals were sound" in Asia, the IBRD (ibid., p. 2) draws parallels with Mexico. Identifying "premature financial liberalization and weak financial discipline in domestic banking systems" as creating vulnerability to speculation, it draws attention to the Southern Cone crisis in 1982 and to Mexico's in 1994-95. In 1990 an audit report by the Bank's own OED on Chile's structural adjustment loans "highlighted the lack of prudential supervision of financial institutions in increasing the economy's vulnerability to the point of collapse." The neglect of proper sequencing and institution building "featured prominently in the Chile and Mexico crises" (ibid.) as the Bank remarked, calling the Chilean experience of 1982 meanwhile a "more relevant" explanation of the Asian crash than "the lessons of the general debt crisis" (ibid.), whatever that may mean. In short, the problem was known years before the crash. The OED's "key lesson" did not make "policy makers and international financial institutions give these weaknesses appropriate weight", who encouraged the same policies in Asia.

One has indeed to ask: "Why did not policymakers and international financial institutions give these weaknesses appropriate weight?" (ibid., p. 2). Why did the BWIs (both not normally known for their restraint in giving advice) not warn those countries to proceed more slowly with cautious sequencing - not even as they do today - pointing at already available evidence, instead of applauding too quick liberalization and those inflows of volatile capital? Before 1994-95 the BWIs had applauded and encouraged inflows to Mexico, presenting them as a proof that the debt crisis was over (Raffer, 1996). Like in the case of Asia official euphoria must certainly have fuelled inflows further.

If Asian countries had not liberalised their economies so quickly and strongly, the crisis could not have happened. Those countries that had liberalised less had no crisis. Money that cannot enter a country can hardly leave it. Sticking to the old Asian model of controlled capital flows would have prevented the crisis, as it prevented a debt crisis of the 1980s or controlled debt problems in the Korean case.

It is most important to recall that the Asian crisis did not come unexpectedly. In fact, the BWIs knew well in advance what would happen, but egged their Asian members on to produce catastrophe. The IBRD acknowledged in an official document that it had known that Asia was heading towards a crash. The "the relevant institutional lessons" (IBRD, 1999, p. 2) had been known well before East Asian Dragons embarked on capital account liberalisation, but instead of warning member countries, IFIs encouraged them to liberalise unduly, apparently for purely ideological reasons.

The lessons of "second generation debt crises" and their effects on the real economy were apparently not really learned, or considered unimportant in relation to speculators' gains. The IMF still voices reservations about those members using their statutory right to capital controls, although meanwhile forced to admit that these 
might be necessary, sometimes as a last resort. The Fund continues privileging speculative capital flows over trade, a 180-degree turn away from its founders' intentions.

Correcting the wrong incentive of capital weights in Basel I would have been an urgent issue for Basle II. But this was not done. Basel II rolled public regulation further back. Internal risk models of financial sector entities were introduced (Lehman Brothers' own internal model calculates Lehman Brothers' risks and thus its capital needs and profits). It gave a particularly strong role to credit rating agencies whose ratings of subprime paper contributed fundamentally to the US crash. According to Fitch (2007, p. 5): “As at June 30, 2007, 'AAA' obligors represented only $1 \%$ of Fitch's corporate and financial institution coverage [...] 'AAA' ratings are much more common for structured finance transactions $(60 \%$ of outstanding ratings at June 30 , $2007)$ due to the ability to 'tranche' securities into various layers." Speculative, toxic and internationally mobile papers were anointed a much lower likelihood of default than real business, another sign of the new lack of importance of the real sector. Pagano \& Volpin (2009, p. 5) remark: "Rating agencies benefited a lot from the growth of structured products." In any case, such ratings (that later proved unfounded) favoured international speculative flows. Luckily, the crisis erupted before Basel II had been fully implemented. Sadly, many profitable investments in the real economy have been squeezed out by this undue preference for the financial sector.

Basel III (revised Basel II really) was already criticised, but fairness demands to wait before judging its effects. Phasing in lasts until 2019. Credit rating agencies remain important. In spite of their record and misgivings in many OECD-countries, whole economies such as Greece or Spain continue to depend on the views of these agencies. Rather than reducing their importance, the EU in particular has increased it, making themselves dependent on the agencies' verdict to the point that the European Financial Stability Facility was initially provided with a cash reserve, $120 \%$ overguarantee and a loan specific cash buffer (EFSF, 2011, p. 1). The "amended EFSF" boasts up to 165 percent overguarantee. In other words, the bail-out institution itself does not trust its own strength and is keen to court CRAs. The EFSF's homepage proudly presented the ratings it received from those three big CRAs that once rated subprime instruments as good as the EFSF.

The European Central Bank also established CRAs as important determinants of collateral eligibility. In 2008 it added DBRS, a small and little known Torontobased CRA that rated conveniently better than the big three. Eligibility is upheld as long as not all CRAs explicitly downgrade. This holds promise of ECB credibility for CRAs from countries such as Nigeria or Uzbekistan if only they are prepared to rate Euro-problem-countries appropriately. Nevertheless the ECB had to suspend ratings requirements for Greek and Irish government bonds. Unlike Europe, China has acted. In July 2010 a Chinese rating agency, Dagong Global Credit Rating Co., Ltd., published its first rating. Because of its debt burden Dagong ranked the US behind China, an opinion meanwhile fully validated by events.

Basel I also gave a risk weight of zero to lending to OECD-countries, a practice retained later. In other words, banks lending to Greece did not have to put any capital aside as security (capital weight of zero). This fuelled lending to Greece or other Mediterranean euro-countries beyond what they should have been able to raise, another contributing factor producing the present European crisis and its 
nefarious effects on the real economy. As spreads of Greek and other papers allowed earning slightly more than on German bonds, regulators practically pushed banks into lending to present problem states.

While making lending to producing (especially small and medium) enterprises, the real task of banks, more difficult, the Basel Committee encouraged capital flows, did not introduce appropriate controls for investment banking, off balance sheet activities, bonds, fancy speculative instruments or shadow banking. Techniques to reduce capital requirements - special vehicles, such as SIVs (Structured Investment Vehicles), SPV (Special Purpose Vehicles), which emerged to keep activities off banks' books and to avoid related capital requirements - were allowed, the role of private rating agencies was increased to push back official regulators. A booming intransparent OTC market emerged. While any insurance company insuring an old bicycle has to meet many conditions to engage in the business of insuring, CDS, e.g., can be sold without similar precautionary regulation. The fact that no one knew the effects of CDS triggered by a Greek default is routinely quoted by those bailing out speculators in the present Greek crisis. The fact that it is the task of regulation to avert and prevent such systemic threats is not even raised.

The preference given to capital movements and speculation over the real economy has increased capital flows to the point where their movements make decisions in the real economy and textbook trade theory irrelevant. There is a basic economic explanation: run away liberalisation and deregulation had made speculative finance not only easy but also so much more profitable than real production.

\section{A NEOCLASSICAL AGENDA OF CONTROLLING CAPITAL FLOWS}

In order to allow neoclassical trade theory to work as posited, countervailing effects of capital flows have to be eliminated, incentives distorted by capital flows have to be corrected. Upholding neoclassical trade theory and its benevolent effects on everyone demands state intervention to safeguard textbook trade mechanisms. Capital controls are thus a necessary element of neoclassical, textbook policies. Only if trade mechanisms are brought back into operation, can these models work, even on their highly abstract level. Liberalising primarily trade transactions (called "current transactions" in the IMF's Articles of Agreement), the Bretton Woods system fostered trade, protecting it against speculative flows. The following proposals of how to reduce or eliminate disruptions caused by capital flows is therefore a deeply and genuinely neoclassical imperative. Intervention is a neoclassical agenda if one takes neoclassical trade theory seriously — unlike orthodox academics.

Obviously, returning to a system such as Bretton Woods is one option. But it is not politically realistic. Neoliberal anti-market forces will not allow its revival. Therefore capital controls on a national or regional scale are more likely. Southern G-20 members and other Southern countries could shape their own regulatory framework. Enough money is available in the South right now. The fact that Sothern countries are establishing their own IFIs - although still in statu nascendi - is encouraging if these new institutions do not commit the error of copying the old 
ones. Trade enhancing and safeguarding interventions require a new theory of trade, a framework determining when and to what extend trade enhancing interventions are to be made.

\section{Towards a New Theory of Trade}

A first step demonstrating this idea is easily made in the customary 2-countries2 -goods world. Interventions must keep exchange rates within the trade interval. Therefore, exchange rate variations beyond the interval's limits must be frustrated. Naturally, identifying these points in practice may be difficult. In theory, though, that would lead to a system with clear similarities to Bretton Woods, less rigid but also less easy to administer.

To some extent the problem recalls the discussion on the Tobin Tax that also aims at stabilising exchange rates by eliminating harmful flows. The "politically feasible" Tobin tax propagated by Spahn (2002) may thus serve as an inspiration. Spahn presented a two-tiers "Tobin-cum-Circuit-Breaker Tax" (TCCBT): a small rate levied continuously combined (to keep track of capital movements) with a high-rate surcharge on externalities resulting from speculation, the "Exchange Rate Normalization Duty" (ERND). The latter responds to exchange rate volatility. Unsurprisingly Spahn (2002, p.18) "was inspired by the EMS (European Monetary System) that was operational in the EU from 1979 until the introduction of the euro." It was based on a target rate, the ECU reference rate - corresponding to a weighted arithmetical average of twelve European currencies - and a target zone (or "corridor") defined as a deviation relative to the target rate of $\pm x$ percent. If the exchange rate threatened to leave the corridor, interventions would be triggered. But in contrast to the EMS, Spahn's target rate of ERND is an adjustable moving average of daily official exchange rates relative to a reference or anchor currency.

A similar mechanism could serve to create a reference zone for the trade interval. One might think of the arithmetical average of exchange rates of the currencies of the G-20 vis-à-vis an international key currency. Due to self-inflicted catastrophe in the eurozone and the way the crisis has been "managed" by the EU's political decision makers (cf., Raffer, 2014), the euro is arguably not a good choice. One would have to think either of the US dollar or the IMF's SDRs, themselves a basket of currencies. Alternatively, one might think of a basket of the important currencies for each country. This would be tailor-made for each individual situation, arguably the optimal solution. Whenever a country's exchange rate vis-à-vis this marker deviates by more than the agreed maximum deviation, the country automatically has the right - preferably even the obligation - to curb capital flows in order to defend the trade interval and thus the textbook pre-conditions for trade in goods and services.

As in the case of Spahn's tax on forex transactions, "the width of the corridor could be determined with regard to empirical data on the daily fluctuations of the exchange rate relative to the target rate under normal circumstances, perhaps with some safety margin in order to trigger the duty not too often. These daily fluctuations could vary for different pairs of currencies" (Spahn, 2002, pp. 19f). Also, one could imagine different bandwidths for different currency pairs, as he suggests. In 
fact, currency-dependent bandwidths might be even more advised than in the case of financial transactions because the composition of trade and thus of foreign currencies in which it is effected, vary from country to country.

Instead of curbing capital flows totally once the trigger exchange rate is reached, one could of course imagine taxes that increase in line with the increasing deviation from the corridor. In this case one would simply implement Spahn's model, primarily with the intent to protect physical trade but technically in the same way. The country could also reserve the right to allow certain essential transactions via licences. In this respect the concept of "current transactions" in the IMF's Articles of Agreement would be helpful as a starting point. These are defined by Article XXX $(\mathrm{d})$ as "payments which are not for the purpose of transferring capital". As in the Fund's statutes one may include

(1) all payments due in connection with foreign trade, other current business, including services, and normal short-term banking and credit facilities;

(2) payments due as interest on loans and as net income from other investments;

(3) payments of moderate amount for amortization of loans or for depreciation of direct investments; and

(4) moderate remittances for family living expenses.

The flexibility given by the Fund's statutes provides once again useful advice:

- in consultation with the members concerned, the Fund may determine whether certain specific transactions are to be considered current transactions or capital transactions (Art. XXX(d)), and

- even current transactions can be restricted, although only with the Fund's approval (Art. VIII(2)(a)).

Article VI(1)(a) goes further, stating that a "member may not use the Fund's general resources to meet a large and sustained outflow of capital except as provided in Section 2 of this Article [referring exclusively to reserve tranche purchases $\mathrm{KR}$ ] and the Fund may request a member to exercise controls to prevent such use of the general resources of the Fund". The mechanisms to control trade distortion established under Bretton Woods are legally still in place. They have been eroded and virtually abolished in practice, a clear violation of the IMF's present statutes in favour of speculation and unhindered capital flows.

Unfortunately, the evolution observed in the case of the IMF is a clear warning. The Fund perverted the intentions of its founders into the exact opposite, the strife to liberalise und deregulate capital. Asian countries had not only the right to control capital outflows - as the IMF had to admit when Malaysia exercised it (cf.,., Raffer and Singer, 2001, p. 157), reducing non-performing loans drastically and saving quite a few firms in the real economy from ruin - but forcing members to finance large and sustained outflows by speculators the IMF openly violated its own constitution, protecting speculators from those countries that control the Fund by their votes.

If one wants to avoid a similar evolution, an unequivocal prohibition would not change anything. Such prohibitions have already been routinely breached. The punishingly difficult task is to make the IMF (and other IFIs) obey their own statues 
or to create new Rule-of-Law-based institutions. Here the South and BRICS in particular, might lead the way.

Technically, the mechanism to keep exchange rates within the trade interval could be domiciled at the IMF, although an explicit re-orientation of this institution with regard to capital flows and the Rule of Law is indispensable. Its present preference for liberalisation and deregulation - even in breach of its own statutes would have to be changed. However, the Fund's record is an extremely clear warning against this option.

Alternatively, a small office at the WTO could do the few and simple tasks that are necessary: calculate the marker. It could check the respective exchange rates and could be officially notified by countries exercising their right to curb capital flows.

The best solution would, of course, be an IFI where Northern (creditor) countries can no longer dominate at will. But a simple problem seems to exist: no Southern country is willing to fight for it. Unlike slaves fighting for their own freedom as well as the abolition of slavery, there is no indication that Southern Countries even consider fighting for their legal rights, nor are exporting industries in the North. The obvious conclusion is logically that Southern Countries will not get what they are not fighting for. Trade will continue to be at the mercy of speculation, and a theory of trade with no connection to reality will continue to be taught at universities. Few economists are prepared to commit crimethink, putting their career at risk merely for rectitude and science.

\section{REFERENCES}

BIS (2011) "History of the Basel committee and its membership", http://www.bis.org/bcbs/history.htm. Bundestag (2001) Öffentliche Anhörung zur Entwicklung der internationalen Finanzmärkte, zur Verschuldungsfrage und zu einem internationalen Insolvenzrecht am Mittwoch, 14. März 2001, Wortprotokoll, Deutscher Bundestag, 14. Wahlperiode, Finanzausschuss, 7. Auschuss, Protokoll Nr. 90 (chair: MP Christine Scheel).

Eichengreen, Barry \& Ashoka Mody (1998) "Interest rates in the north and capital flows to the south: Is there a missing link?” International Finance 1(1), pp. 35ff, or at http://www.blackwell-synergy.com/ doi/pdf/10.1111/1468-2362.00003 (accessed 4 August 2009).

ESFS Newsletter (2001) "Europe moves ahead with crisis resolution", $\mathrm{N}^{\circ}$ 2, July.

Fitch (2007) "Inside the ratings: what credit ratings mean”, http://www.securitization.net/pdf/Fitch/ CreditRatings_7Aug07.pdf.

Helleiner, Eric (2014) Forgotten Foundations of Bretton Woods: International Development and the Making of the Postwar Order, Ithaca and London: Cornell University Press.

Helleiner, Eric (no year) The Contemporary Reform of Global Financial Governance: Implications of and Lessons from the Past, G24 Paper, http://www.g24.org/hell0309.pdf.

IBRD (1999) OED, 1998 Annual Review of Development Effectiveness, Task Manager: Robert Buckley, IBRD, Washington DC 1999.

IMF (2014) World Economic Outlook, April.

Kaufman, Frederick (2011) "How Goldman Sachs created the food crisis", Foreign Policy 27 April, http:// www.foreignpolicy.com/articles/2011/04/27/how_goldman_sachs_created_the_food_ crisis? page $=0,1$.

Krugman, Paul, R. \& Maurice Obstfeld (2009) International Economics, Theory and Policy, $8^{\text {th }}$ edition, Boston: Pearson.

Ostry, Jonathan D., A.R. Ghosh, K. Habermeier, L. Laeven, M. Chamon, M.S. Qureshi \& A. Kokenyne 
(2011) “Managing capital inflows: what tools to use?” Authorized for distribution by Olivier Blanchard, IMF Staff Discussion Note, April 5.

Ostry, Jonathan D., Atish R. Ghosh, Karl Habermeier, Marcos Chamon, Mahvash S. Qureshi \& Dennis B.S. Reinhardt (2010) “Capital Inflows: The Role of Controls”, http://www.imf.org/external/pubs/ $\mathrm{ft} / \mathrm{spn} / 2010 /$ spn1004.pdf.

Pagano, Marco \& Paolo Volpin (2009) “Credit ratings failures and policy options”, Economic Policy, Fiftieth Panel Meeting Hosted by the Universiteit van Tilburg, 23-24 October, http://www.cepr.org/ meets/wkcn/9/977/papers/PaganoVolpin.pdf.

Raffer, Kunibert (1994) "Disadvantaging comparative advantages: the problem of decreasing returns", in Renée Prendergast \& Frances Stewart (eds), Market Forces and World Development, Basingstoke: Macmillan, pp. 75-90. Reprint in: H.W. Singer, N. Hatti \& R. Tandon (eds) New World Order Series, vol. 20: Trade and Growth; Models and Methods, B.R. Publishing, Delhi 2003, pp. 285-304.

Raffer, Kunibert (1987) Unequal Exchange and the Evolution of the World System, Reconsidering the Impact of Trade on North-South Relations, London: Palgrave Macmillan.

Raffer, Kunibert (1996) "Is the debt crisis largely over? - a critical look at the data of international financial institutions", in; Richard Auty and John Toye (eds) Challenging the Orthodoxies, London/Basingstoke: Macmillan.

Raffer, Kunibert (2010) Debt Management for Development. Protection of the Poor and the Millennium Development Goals, Cheltenham, UK/Northampton, US: Edward Elgar.

Raffer, Kunibert (2011) "Global Imbalances and the US Crisis: Is a Bad Excuse Really Better than None?" in Mansoob Murshed, Pedro Goulart \& Leandro Serino (eds) South-South Globalization Challenges and Opportunities for Development, London/New York: Routledge: pp. 61-78

Raffer, Kunibert (2014) “Turning a small problem into catastrophe: the case of Greece”, In D. Dăianu, G. Basevi, C. D'Adda \& R. Kumar, The Eurozone Crisis and the Future of Europe, Basingstoke: Palgrave Macmillan, pp. 154-170.

Raffer, Kunibert \& H.W. Singer (2001) The Economic North-South Divide, Six Decades of Unequal Development, Cheltenham (UK), Northampton (US): Edward Elgar.

Rose, Andrew K. \& Eric van Wincoop (2001) "National money as a barrier to international trade: the real case for currency union", American Economic Review, 91(2), pp. 386-390.

Samuelson, Paul (1948) "Disparity in post-war exchange rates", in S.E. Harris (ed) Foreign Economic Policy for the US, Cambridge (Mass): Harvard University Press.

Spahn, Paul Bernd (2002) "On the feasibility of a tax on foreign exchange transactions", Report to the Federal Ministry for Economic Cooperation and Development, Bonn, Frankfurt am Main.

Viner, Jacob (1937) Studies in the Theory of International Trade, London: Allen \& Unwin. 